\title{
Pemberdayaan Remaja Bodeh Sebagai Kader Reproduksi Sehat
}

\author{
Sri Sundari1*, Muh. Khotibuddin² \\ ${ }^{1.2}$ Program Studi Kedokteran, Fakultas Kedokterandan IlmuKesehatan, Universitas Muhammadiyah Yogyakarta \\ Mail: sundari_purbo@yahoo.com.sg \\ DOI: 10.18196/ppm.32.186
}

\begin{abstract}
Abstrak
Berdasarkan data yang dilansir dari Survei Kesehatan Reproduksi Remaja di Indonesia tahun 2010, pengetahuaan mengenai kesehatan reproduksi dan seksualitas di kalangan remaja masih terbilang rendah. Pergaulan bebas yang seringkali terjadi tanpa disertai pengetahuan tentang kesehatan reproduksi yang baik merupakan suatu kondisi yang sangat menyedihkan dan membahayakan. Masuknya kebudayaan yang mengubah tata nilai disebabkan oleh komunikasi global dan perubahan/inovasi teknologi. Oleh karena itu, perlu adanya bekal tentang pemahamam dan pengetahuan tentang reproduksi yang sehat bagi remaja. Pada pengabdian ini, dilakukan pengukuran pengetahuan peserta sebelum dan setelah diberikan pembelajaran tentang reproduksi sehat. Pemberian pengetahuan dengan diberikan flyer yang bisa dipelajari secara mandiri dan edukasi langsung secara online. Hasil pengabdian menunjukkan bahwa dengan pemberian edukasi secara tidak langsung dan dikombinasi secara langsung mampu meningkatkan pengetahuan peserta tentang kesehatan reproduksi remaja dari $59 \pm 17,3$ menjadi

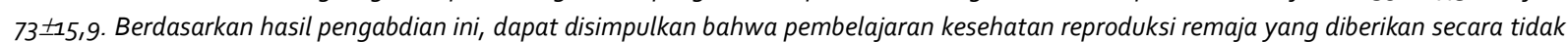
langsung dan dikombinasi dengan metode langsung dapat meningkatkan pengetahuan secara signifikan.
\end{abstract}

Kata kunci: Pendidikan, reproduksi remaja, Kesehatan

\section{Pendahuluan}

Hasil penelitian suatu lembaga di Kota Yogya menyatakan 97,05\% mahasiswi dari 1.660 responden telah melakukan hubungan seks pranikah. Pusat Penelitian Kependudukan UGM (1991) mengungkapkan 26,6\% dari 151 remaja pria dan 146 perempuan antara 14- 21 tahun di Manado melakukan perilaku seks pranikah. Lembaga Konselor Sahabat Remaja di Medan melaporkan data tahun 1990 ada 80 remaja usia 14-24 tahun hamil sebelum menikah. (Tempo, 28 September 1991).

Dampak dari kurangnya pendidikan kesehatan reproduksi mengakibatkan tidak kurang dari 7.000 kasus baru HIV yang separuhnya adalah remaja. Virus HIV menyebar karena sikap, pengetahuan, ketidakpedulian, dan hubungan seks yang bersifat heteroseksual. Pada akhir tahun 2001 tidak kurang dari 11,8 juta remaja usia 15-24 tahun sedang mengidap Virus HIV dan penyakit AIDS yang hampir tidak bisa disembuhkan. Di Asia Selatan dan Asia Tenggara terdapat sekitar 5,6 juta penderita HIV/AIDS. Sekitar 780.000 orang terkena infeksi baru virus itu setiap tahunnya. HIV hanyalah salah satu akibat dari sikap ketidakpedulian dan kurangnya pengetahuan tentang reproduksi remaja. Masih banyak masalah lain yang segera memerlukan penanganan yang sungguh-sungguh.

Upaya mempelajari kesehatan reproduksi remaja, membentengi diri dengan ketahanan yang tinggi, dan menghindari sikap dan tingkah laku reproduksi yang merugikan diri sendiri perlu ditumbuhkan. Para remaja, baik laki-laki maupun perempuan, lebih banyak bergaul, belajar, dan bekerja bersama dengan akrab di sekolah, mulai Taman Kanak-Kanak hingga perguruan tinggi. Mereka bergaul dalam kurun waktu yang lama, bisa sampai seperempat abad. Selama masa pergaulan yang panjang, anak-anak mengalami perubahan, mulai dari lingkungan di sekelilingnya, dalam diri dan tubuh mereka, dalam pikiran mereka, dan tentu saja dalam aspirasi yang makin luas dengan segala implikasinya. Karena perubahan-perubahan itu, sikap reproduksi dan hubungan mereka sebagai teman sebaya pun berubah. Persahabatan yang semula biasa-biasa saja, makin lama bisa diikuti oleh perkembangan sikap dan motivasi reproduksi. Pertumbuhan dan perkembangan itu seharusnya segera diikuti oleh pemberdayaan 
yang baik tentang reproduksi. Akan tetapi, pada kenyataannya para remaja itu belajar masalah reproduksi dari teman- temannya sendiri dengan tingkat akurasi yang rendah. Orang tua di rumah tidak siap menjadi guru untuk anak-anak remajanya. Informasi yang bisa diberikan kepada remaja mereka juga tidak akurat. Sekolah-sekolah tidak berani mengadakan pelajaran tentang reproduksi karena takut dituduh memberikan advokasi atau pendidikan tentang masalah seks. Masyarakat tidak berani membentuk lembaga yang memberikan pelajaran reproduksi karena takut dituduh mengadakan pendidikan tentang masalah seksual kepada anak-anak remaja. Seiring dengan kemajuan ilmu dan teknologi, media massa, televisi, surat kabar, majalah, pusat-pusat hiburan, dan banyak tontonan lain memberikan ekspos cerita dan gambar-gambar yang berbau seks. Anak-anak muda yang bergaul demikian lama dengan sesamanya mudah terangsang. Tanpa adanya pengertian dan pengetahuan yang memadai, dengan mudah hal itu bisa terjadi.

Kecelakaan reproduksi berupa kehamilan sebelum pernikahan, menjalarnya penyakit menular seksual, HIV/ AIDS, dan atau kecelakaan reproduksi lainnya dapat terjadi. Perubahan perilaku seks pranikah di kalangan remaja tidak terlepas dari beberapa factor, pertama hasil percontohan (modeling). Salah satunya adalah terbukanya akses informasi seksual. Informasi dapat diperoleh melalui media elektronika seperti siaran televisi, video, LCD, VCD, dan media cetak bahkan teknologi modern, yakni internet. Berbagai tindakan kekerasan seksual terjadi di berbagai penjuru tanah air. Hal ini terjadi karena peniruan perilaku reproduksi yang tidak tepat. Kedua, adanya anggapan informasi seks hanya menjadi otoritas kaum dewasa dan bukan anak-anak dan remaja sehingga seks yang hadir dalam kehidupan remaja tidak dikenal secara utuh dan terpotong-potong. Hal ini akan memicu rasa keingintahuan yang mendalam dan mencoba mencari kepuasan lewat eksplorasi yang salah. Hal ini ditambah lagi, tidak memungkinkan untuk membicarakan seks secara terbuka dalam keluarga karena adanya rasa "tabu". Ketiga, perubahan perilaku seks di kalangan remaja Indonesia. Hal ini disebabkan munculnya sikap permisif terhadap hubungan seks pranikah. Keadaan ini dipicu oleh berbagai macam tayangan, terbitan media cetak, dan elektronik pascareformasi sehingga memunculkan gaya hidup baru menuju perilaku seks bebas. Hal hal tersebut di atas seakan menjadi pencetus beberapa fakta mengenai aborsi yang akhir-akhir ini menunjukkan jumlah yang cukup mengagetkan. Budi Utomo dan kawan-kawan dalam penelitiannya di 10 kota besar dan 6 kabupaten, menemukan bahwa per tahun terdapat 2 juta kasus aborsi, atau 37 aborsi per 1000 perempuan usia 15-49 tahun, atau 43 aborsi per 100 kelahiran hidup, atau 30\% kehamilan. Sebuah klinik di Jakarta memperkirakan rata-rata terdapat sekitar 100-500 pasien yang meminta aborsi di klinik tersebut setiap bulannya. Dari sisi perbandingan jumlah aborsi di kota dan desa hampir sama. Kasus aborsi di perkotaan dilakukan secara diam-diam oleh tenaga kesehatan, sebanyak $73 \%$. Sementara di pedesaan sebagian besar dilakukan secara diam-diam oleh dukun, sebanyak 84\%. Aborsi yang dilakukan secara diam-diam inilah yang menempatkan perempuan harus menanggung risiko bila terjadi kematian karena komplikasi perdarahan dan infeksi. Bertitik tolak dari fakta tersebut di ata,s kita harus mengambil langkah strategis mempersiapkan anak-anak muda dengan pengetahuan yang mendalam tentang masalah-masalah reproduksi. Setiap keluarga harus mempunyai komitmen yang tinggi terhadap masalah reproduksi agar tingkat kematian ibu karena mengandung dan melahirkan dapat segera diturunkan. Pemerintah dan masyarakat harus bahu membahu mempersiapkan diri untuk itu. Dengan demikian, program-program dukungan untuk menyelamatkan reproduksi generasi muda dapat dikembangkan dengan lebih baik. Dengan bekal pengetahuan yang diberikan, diharapkan para remaja dapat menjadikannya sumber pengetahuan dan dapat menyebarluaskan pengetahuan tentang reproduksi sehat yang sesuai dengan ajaran Islam serta dapat menjadi rujukan bagi teman sebayanya. 


\section{Metode Pelaksanaan}

Kemampuan remaja dalam menghadapi kondisi lingkungan yang berubah yang dikawatirkan akan menimbulkan dampak merugikan dapat antisipasi dengan memberikan pelatihan cara menghadapi perubahan lingkungan pergaulan yang dialami dan memberikan bekal pengetahuan yang cukup mengenai reproduksi yang sehat. Pemilihan sampel pada pengabdian ini adalah semua remaja yang tergabung dalam kelompok remaja di RW 24 dan 25 Dusun Bodeh. Salah satu caranya adalah dengan diberikan pelatihan mengenali penyakit yang memengaruhi perkembangan reproduksi. Pelatihan ini akan diberikan melalui dua metode, dan yakni metode pertama dengan memberikan flyer secara langsung yang bisa dipelajari sendiri, metode kedua dengan memberikan pelatihan masing-masing $2 \mathrm{x}$ pertemuan. Untuk bekal pengetahuan mereka, akan dikembangkan modul yang dapat dipelajari oleh para remaja secara mandiri sebagai acuan dalam menyebarkan pengetahuan kepada teman sebaya. Sebelum dilakukan intervensi dengan memberikan flyer dan pelatihan, pengetahuan mereka tentang kesehatan reproduksi diukur dengan menggunakan google form. Setelah intervensi pengetahuan mereka, kesehatan reproduksi remaja diukur kembali. Selain itu, mereka diminta untuk memberi masukan terkait pelatihan yang diberikan secara terbuka. Hasil asesment yang dilakukan dianalisis dengan menggunakan pairs t-test.

\section{Hasil dan Pembahasan}

Responden dari pengabdian ini adalah semua remaja di Dusun Bodeh yang bersedia mengikuti pelatihan. Jumlah peserta terdiri atas tiga puluh orang. Pelatihan ini direncanakan akan dilakukan dengan tatap muka langsung dan penyebaran flyer. Akan tetapi, karena kondisi pandemic Covid-19, pelaksanaan tatap mjuka diganti secara online. Adapun gambaran karakteristik responden yang terlibat dalam pengabdian ini dapat dilihat pada tabel 1 .

Tabel1. Gambaran Karakteristik Responden Pengabdian Masyarakat di Dusun Bodeh

\begin{tabular}{llll}
\hline No & Karakteristik & Jumlah & Persentase \\
\hline 1 & Usia & & \\
& $16-19$ tahun & 12 & 40 \\
& $\geq 20$ tahun & 18 & 60 \\
\hline 2 & Jenis Kelamin & & \\
& Laki-laki & 16 & 53 \\
& Perempuan & 14 & 47 \\
\hline 3 & Pendidikan & & \\
& SMA/sederajat & 20 & 67 \\
& SD & 10 & 33 \\
\hline
\end{tabular}

Berdasarkan tabel di atas, diketahui bahwa mayoritas responden adalah laki-laki dengan pendidikan SMA/sederajat. Sebagian besar responden sudah bekerja dan sebagian masih melanjutkan pendidikan ke perguruan tinggi. Responden merupakan remaja aktif yang terkumpul dalam kegiatan kepemudaan di Dusun Bodeh. Hasil pelatihan secara detail dapat dilihat pada gambar 1 . 


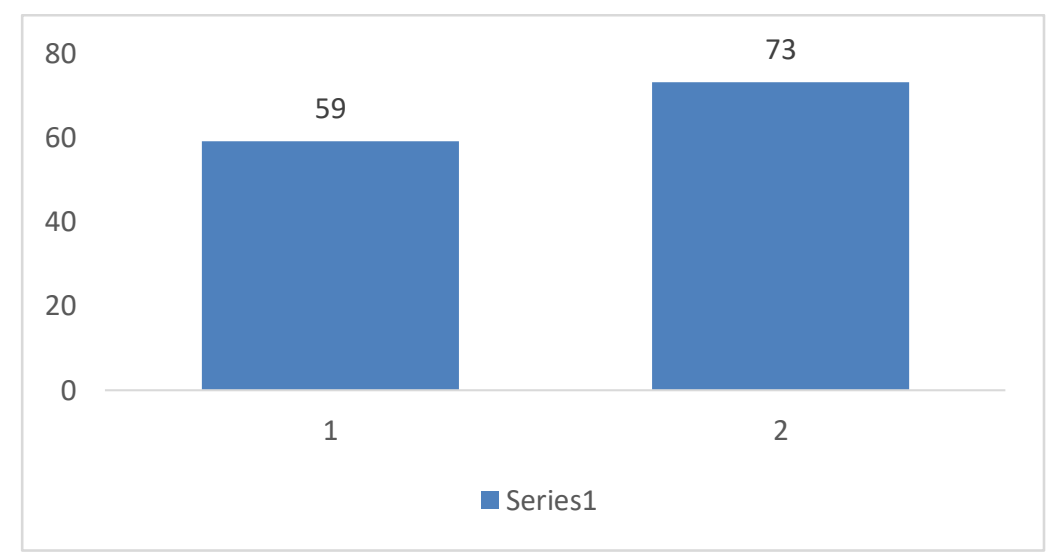

Gambar 1. Hasil Pelatihan Kesehatan Reproduksi

Dari gambar 1 terlihat bahwa pengetahuan rata-rata yang dimiliki remaja Bodeh sebelum diberikan pelatihan sebesar $59 \pm 17,3$. Hal ini menunjukkan bahwa pengetahuan tentang kesehatan reproduksi remaja di Bodeh masih rendah. Remaja memiliki rasa ingin tahu yang besar. Keinginan ini sering tidak dibarengi dengan pemikiran dan pertimbangan yang matang sehingga akan membawa ke tindakan yang berisioko, baik terhadap dirinya sendiri maupun terhadap lingkungan. Salah satu masalah yang timbul adalah kesehatan reproduksi. Kesehatan reproduksi merupakan keadaan kesehatan fisik, mental, dan sosial yang sangat penting untuk dimengerti oleh remaja. Dalam hal ini pembahasan tidak hanya mengenai hubungan seksual. Tidak adanya informasi yang akurat menyebabkan remaja mencari dan mendapatkan informasi mengenai kesehatan reproduksi dari sumber-sumber yang kurang terpercaya, seperti teman-temannya atau dari media-media yang tidak bisa dipertanggung jawabkan. Pubertas membuat remaja sadar akan potensinya dan menjadi lebih ekspresif dalam mengeksplorasi organ dan perilaku seksualnya. Persepsi mengenai kesehatan reproduksi dan seksualitas yang salah dapat ikut terbawa ke dalam perilaku seksual mereka. Miskonsepsi ini dapat meningkatkan perilaku seks berisiko dan mengakibatkan risiko terkena penyakit menular seksual. Penyakit ini dapat berupa keputihan, Klamidia, Gonorea, hingga HIV AIDS. Apabila dibiarkan, penyakit tersebut dapat mengakibatkan infeksi lebih lanjut dan membahayakan dirinya. Untuk memberikan pengetahuan kesehatan reproduksi yang baik, tentunya butuh kerja sama dari berbagai pihak, mulai dari orang tua yang dapat memberikan pengetahuan tentang kesehatan reproduksi yang disesuikan dengan usia anak sejak dini. Kegiatan ini dapat dikombinasikan dengan pemberian pengetahuan kesehatan reproduksi yang diberikan di sekolah. Hal ini sejalan dengan hasil penelitian yang disebutkan oleh Mazfiah dkk (2016) bahwa untuk memperbaiki pengetahuan tentang kesehatan reproduksi sebaiknya pengetahuan ini diberikan secara terstruktur di sekolah, baik secara intrakurikulum maupun ekstra kurikulum. Dari penelitian terdahulu disebutkan bahwa peningkatan pengetahuan ini bisa dilakukan lebih baik dengan cara mengintegrasikan pendidikan ke dalam kurikulum. Selain itu, pelayanan kesehatan reproduksi harus dilakukan sedini mungkin, yaitu sejak remaja. Pelayanan itu diberikan melalui layanan kesehatan reproduksi remaja (Susiana, 2016).

Dari hasil pengabdian juga diketahui bahwa dengan pendidikan nonformal, pengetahuan bisa disampaikan dan dipahami dengan baik. Hal ini terlihat dari hasil post test yang meningkat secara signifikan dengan rata- rata nilai post tes $73 \pm 15,9$. Dari hasil masukan secara terbuka, juga diketahui bahwa para remaja ini merasa pengetahuan yang diberikan sangat bermanfaat dan menambah wawasan mereka sehingga mereka paham bahwa seorang yang menginjak usia remaja perlu menjaga dan mempersiapkan reproduksi yang sehat. Oleh 
karena itu, pendidikan kesehatan reproduksi yang diberikan sedini mungkin oleh orang tua dengan mempertimbangkan usia dan perkembangan anak akan memiliki dampak yang sangat baik terhadap pengetahuan mereka. Hal ini akan memiliki dampak yang lebih baik lagi jika dibarengi dengan pendidikan reproduksi yang diintegrasikan ke dalam kurikulum dan diberikan secara terstruktur.

\section{Simpulan}

Berdasarkan hasil pengabdian dapat disimpulkan bahwa pelatihan pendidikan kesehatan reproduksi remaja yang diberikan secara tidak angsung dan dikombinasi dengan pelatihan langsung dapat meningkatkan pengetahuan responden tentang kesehatan reproduksi.

\section{Ucapan Terima Kasih}

Kami ucapkan terima kasih kepada Lembaga Penelitian, Publikasi dan Pengabdian Masyarakat UMY yang telah memberikan support dana pelaksanaan pengabdian ini melalui SK LP3M No:031/Pen-P3M/2020.

\section{Daftar Pustaka}

Ahmawalily, H. 2010. Kesehatan Reproduksi Remaja (KRR) ; Perhatian Besar bagi Islam. Fokus Edisi 30. http://www.rahima.or.id. Diakses: 9 Agustus 2011.

BKKBN. 2008. Transformasi Sosial dan Perilaku Reproduksi Remaja. http://ceria.bkkbn.go.id/referensi/substansi/detail/174. Diakses: 20 Okt 2020.

BKKBN. 2011. Pengetahuan Remaja tentang Kesehatan Reproduksi Masih Rendah. http://www.bkkbn.go.id/Webs/index.php/berita/detail/2783. Diakses: 20 Okt 2020.

Data Profil Kesehatan Indonesia Tahun 2000, dalam AD. Eridani, Seksualitas dan Kesehatan Reproduksi Remaja : Sebuah Temuan, disampaikan pada Seminar Nasional Seksualitas dan Kespro Remaja di PP. Nuris, Jember-Jawa Timur, Juni 2009.

Data Statistik dengan Menggunakan Definisi WHO tentang Remaja Tahun 1998, dalam http://www. datastatistik-indonesia.com

Dianawati, A. 2003. Pendidikan Seks untuk Remaja. Jakarta: Kawan Pustaka. Ditjen PPM \& PL

Depkes RI. 2011. Statistik Kasus HIV/AIDS di Indonesia. http://www.aidsindonesia.or.id/repo/LT1Menkes2010.pdf. Diakses: 10 Sept 2020.

Djaelani, J., Kebijakan Pelayanan Kesehatan Reproduksi Remaja, dalam Seminar Nasional tentang Hak dan Kesehatan Reproduksi: Implikasi Pasal 7 Rencana Tindakan Kairo bagi Indonesia, Yogyakarta, Mei 1995 http://newspaper.pikiran rakyat.com/prprint.php mib=beritadetail\&id=85651, diakses pada tanggal 2 Sept 2020

Masfiah, S., Shauhiyah, Z., dan Suryoputro, A., 2016. Pendidikan Kesehatan Reproduksi 
Remaja (PKRR) Dalam Kurikulum SMA dan Pengetahuan \& Sikap Kesehatan Reproduksi Siswa. Jurnal Promosi Kesehatan Indonesia 8(1): 69-78 diakses 23 Okt 2020

Susiana, S. 2016. Aborsi dan Hak Kesehatan Reproduksi Perempuan. Info Singkat Kesejahteraan

Sosial, Vol. VIII (6) No. 06/II/P3DI/Maret/2016

Kartono Mohamad, 2009. Seks dan Mitos-mitosnya, dalam Pengantarnya pada Mitos Seputar Masalah Seksualitas dan Kesehatan Reproduksi, Yayasan Mitra Inti, Jakarta. 